\title{
Augmented Reality (AR) as an Enhancement Teaching Tool: Are Educators Ready for It?
}

\author{
Chooi Yi Wei \\ Universiti Tunku Abdul Rahman, Perak, Malaysia \\ ORCID: 0000-0002-3727-0464 \\ Yoke Chin Kuah \\ Universiti Tunku Abdul Rahman, Perak, Malaysia \\ ORCID: 0000-0003-3016-5677 \\ Chee Pung Ng \\ Universiti Tunku Abdul Rahman, Perak, Malaysia \\ ORCID: 0000-0003-3706-5302 \\ Wai Kwan Lau \\ Universiti Tunku Abdul Rahman, Perak, Malaysia \\ ORCID: 0000-0003-0369-2586
}

Received: 30 Sep 2020

Accepted: 25 Jan 2021

\begin{abstract}
The rapid technological development and revolution have transformed the education field, promoting the betterment of learning and teaching quality. Augmented Reality (AR) is becoming increasingly popular for its ability to help educators to create an engaging and creative method of teaching. The increasing use of technology has piqued researchers' interests in studying its efficiency. Following this observation, this study aims to explore educators' readiness in embracing AR as an enhancement teaching tool in the future. This study employed a quantitative methodology and collected 223 respondents' data from five private universities in Malaysia. The data was analysed using the Partial Least Squares - Structural Equation Modelling (PLS-SEM) software. The results demonstrated that there were significant relationships between educators' innovation towards the intention to adopt AR moderated by perceived usefulness (PU) and perceived ease of use (PEU). This study provides some insightful AR applications in the education industry, which is in line with the Industrial Revolution 4.0 theme. It successfully identifies the importance of motivating educators and students in embracing AR as an enhancement learning tool, providing a valuable discussion for the government, learning institutions, and educators on the implementation of AR in Malaysia.
\end{abstract}

Keywords: augmented reality, educator innovation, technology acceptance model, perceived ease of use, perceived usefulness

\section{INTRODUCTION}

The significant progress of current technology has made an impact on the teaching and learning process. Recent years have seen that digital materials and e-learning tools being heavily incorporated in the education industry. Its practicality is further demonstrated during the disruptive period caused by the COVID-19 pandemic - since schools and universities are not able to function normally, educators switched to digital 
teaching and learning platform to continue teaching. Such a significant impact increases educators' awareness of the need to adopt technology in their teaching and learning process.

The incorporation of technology in education has been observed to have positive and construction impacts, particularly when combined with adequate pedagogical foundations. Some researches agree that technology-embedded education encourages more innovative and interactive forms of teaching and learning process, increasing students' motivations (Bursali \& Yilmaz, 2019; Ebenezer, Kaya, \& Kassab, 2018; Fuchsova \& Korenova, 2019; Kaewunruen, 2019; Shapley, Sheehan, Maloney, \& Caranikas-Walker, 2011), while also increasing students' efficacy of learning experiences in the actual world (Weng et al., 2016).

Furthermore, the integration of technology has transformed the learning environment into a more engaging, interactive, authentic, and joyful environment (Cheng, 2018; Gan \& Balakrishnan, 2018). Various technologies such as multimedia, internet, mobile devices, Internet of Things (IOT), virtual reality, and AR are integrated into the education system (Kiryakova, Angelova, \& Yordanova, 2018). The AR was pioneered by Sutherland (1968) - he developed and introduced the AR interface, which used the head-mounted display to depict 3D graphics. Azuma (1997) has further surveyed on the features of Augmented Reality technology and the tradeoffs between video blending and the optical interventions which served as starting point for AR research. Afterwards, numerous conferences on AR were held, such as the International Symposium on Mixed Reality, the International Workshop and Symposium on Augmented Reality, and the Designing Augmented Reality Environments Workshop.

Real objects are an integral part of AR environments, but a virtual design of some of these environments are also needed for its development. This technology does not require detailed 3D models as it has a significant representation of reality, allowing its users to engage directly and spontaneously with virtual objects through the manipulation of actual objects without the use of costly and sophisticated hardware components (Wojciechowski et al., 2004). Compared to virtual reality, AR users are able to have direct face-to-face contact with each other. Since recent studies tend to focus on virtual reality, the potential of AR as an enhancement teaching tool is yet to be discussed.

The AR technology allows users to experience the visualisation of virtual objects that coexists in the real world (Azuma, 1997), making it a suitable interactive tool to grab students' attention in their learning process (Ma et al., 2016) as it can be used for a lesson such as the three-dimensional anatomy of animals and humans (Kiryakova et al., 2018). Lin, Chen, and Chang (2015) discover that AR-assisted teaching proposal demonstrates the feasibility of AR usage and is highly recommended to be incorporated in teaching materials as it can increase students' learning autonomy. The technology is also able to incorporate elements such as connectivity and activities that are consistent with the learners' needs (Kiryakova et al., 2018), subsequently increasing their motivation.

\section{LITERATURE REVIEW}

Studies pertaining to AR technology discovers that it offers a range of advantages, especially in the education field (Garzón, Pavón, \& Baldiris, 2019; Hockly, 2019; Kiryakova et al., 2018; Masmuzidin \& Aziz, 2018; Richardson, 2016; Yip et al., 2019). Nonetheless, its application as an enhancement teaching tool is still yet to be discussed adequately. It has demonstrated its ability in other fields, such as providing on-site experiences to reduce the information gap about the real world and improving efficiency and productivity in manufacturing, training, and product development (Porter \& Heppelmann, 2017). It has also been used to improve the education systems for learners and staffs in academic and corporate settings (Richardson, 2016; Lee, 2012), and to provide immersive and student-centred learning for medical students on their anatomical education (Kugelmann et al., 2018; Moro et al., 2017). Furthermore, Karakus, Ersozlu, and Clark (2019) pointed out AR technology enables the learner to build team spirit among other learners for knowledge gain purposes.

The implementation of AR is typically perceived as costly (Garzón et al., 2019), particularly if it is to be integrated into the education sector. Nonetheless, it has been implemented through the integration of digital 
technology and advanced devices in an effort to improve the education setting (Ozdemir, 2018). The technology's instructional value can be based on both its application and as a notion in the teaching and learning environments (Wu et al., 2013), making the environments more engaging and enjoyable for the students, ultimately increasing their interest and motivation (Acosta et al., 2019; Chang et al., 2020; Kiryakova et al., 2018).

Furthermore, Garzón and Acevedo (2019) assess the difference between the use of AR and other pedagogical tools and discover that learners are better at exploring and understanding the concepts when AR is adopted and implemented as the medium of delivery. Several studies corroborate this notion (Abrar et al., 2019; Garzón \& Acevedo, 2019; Tekedere \& Göker, 2016), while one claiming that AR helps educators to deliver the contents more efficiently in terms of physical, cognitive, and contextual views, enabling students to comprehend the abstract concepts betted (Bujak et al., 2013). Addition to the point above, Hiranyachattada and Kusirirat (2020) also proven that mobile AR effectively applied as a teaching tool for demonstrating the $3 \mathrm{D}$ rendering work concept to the students in a university in Thailand.

The AR technology's core benefits in education are assisting practical skills, spatial ability, and conceptual understanding, in addition to allowing inquiry-based activities (Cheng \& Tsai, 2013). Furthermore, the technology helps to reduce the exorbitant cost of teaching resources such as laboratory equipment and supplies, in addition to providing a safe environment for unskilled learners to explore the potentially hazardous environment. Following these advantages of AR, this study aims to analyse and discover educators' readiness in adopting the AR technology for teaching purposes.

\section{Augmented Reality in Education}

Past studies that analyse the potential advantages of $A R$ and its possible technology design to be implemented in learning, such as Bujak et al. (2013), claim that the AR technology has great potential to be positively implemented in the education field and to increase educators' teaching competency. The technology is able to transform dull and monotonous learning instructions into an exciting and engaging environment (Ibáñez et al., 2014; Kim et al., 2018; Lu \& Liu, 2015; Savela et al., 2020), eventually improving the students' performances (Akçayır \& Akçayır, 2017; Squires, 2017; Liu \& Tsai, 2013). Muñoz Cristóbal et al. (2015) support these researches while explaining that AR improves student engagement within due course. Huang, Li, and Fong (2016) observe that stakeholders - class teachers, principal, ICT teachers, and parents in Hong Kong display a positive response towards the emerging use of technology in the teaching and learning process. Educators' attitude towards AR is pertinent in the implementation of AR as a teaching tool.

The intention and readiness are mainly affected by PU (Pikkarainen, Pikkarainen, \& Karjaluoto, 2004), which inspires users to take on progressive and user-friendly technology that delivers more freedom. As demonstrated by Hassanzadeh, Kanaani, and Elahi (2012), technical intention influence the use of online learning in Iranian universities. Motaghian, Hassanzadeh, and Moghadam (2013) further support the study by proving that PEU, PU, and system quality can influence instructors' intention to employ web-based learning systems in two e-learning pioneer universities in Iran.

In terms of attitude, acceptance of new technologies varies among different individuals - they might adapt or refuse new technologies. Therefore, it is believed that educators' attitudes towards new technologies influence the effectiveness of the product application in the teaching and learning processes. Highlighting the educators' attitudes towards AR applications is critical in assessing the possibility of successful implementation of AR technology in the education sector. It is worth noting that there is a lack of studies on educators' attitudes towards AR applications.

\section{Technology Acceptance Model (TAM)}

In this study, the TAM (Davis, 1989) was employed to examine the educators' readiness in adopting AR as an enhancement teaching tool. The model states that the PU variable - an individual's belief that a technology system will increase performances - is determined by PEU - an individual's belief on the technology system's ease of use, operation, and maintenance (Davis, 1989). The model also assesses the acceptance of a 
technology-based on a user's attitude and intention to use the technology, which are determined by their PU and PEU of the technology. The PU and PEU can be influenced by external factors - the factors considered in this study are personal innovation (PI) and educator's awareness (EA) on AR. The PI pertains to the educator's existing knowledge on the technological related devices, while Educator's Innovation on AR pertains to the information related to AR that is accessible to the educators before this study. The TAM is used to examine if the educator believes that the technology will generate positive or negative impacts on the teaching and learning process.

The TAM has been used in previous studies (Fathema, Shannon, \& Ross, 2015; López Belmonte et al., 2019; Scherer, Siddiq, \& Tondeur, 2019; Zaineldeen, Hongbo, \& Hassan, 2020), with some demonstrate the factors that positively influence an individual's technology acceptance (Huang et al., 2020; Siyam, 2019; Teeroovengadum, Heeraman, \& Jugurnath, 2017). Some studies claim that the original TAM lack several attributes that may influence computer acceptance (Siyam, 2019; Zaineldeen et al., 2020). Meanwhile, Alalwan et al., (2018), Al-Daihani (2016), and Lee, Kim, and Choi (2019) prove the significant positive influence between the perceived enjoyment on using the technology system and suggested the characteristic be included in the TAM.

\section{Theoretical Model}

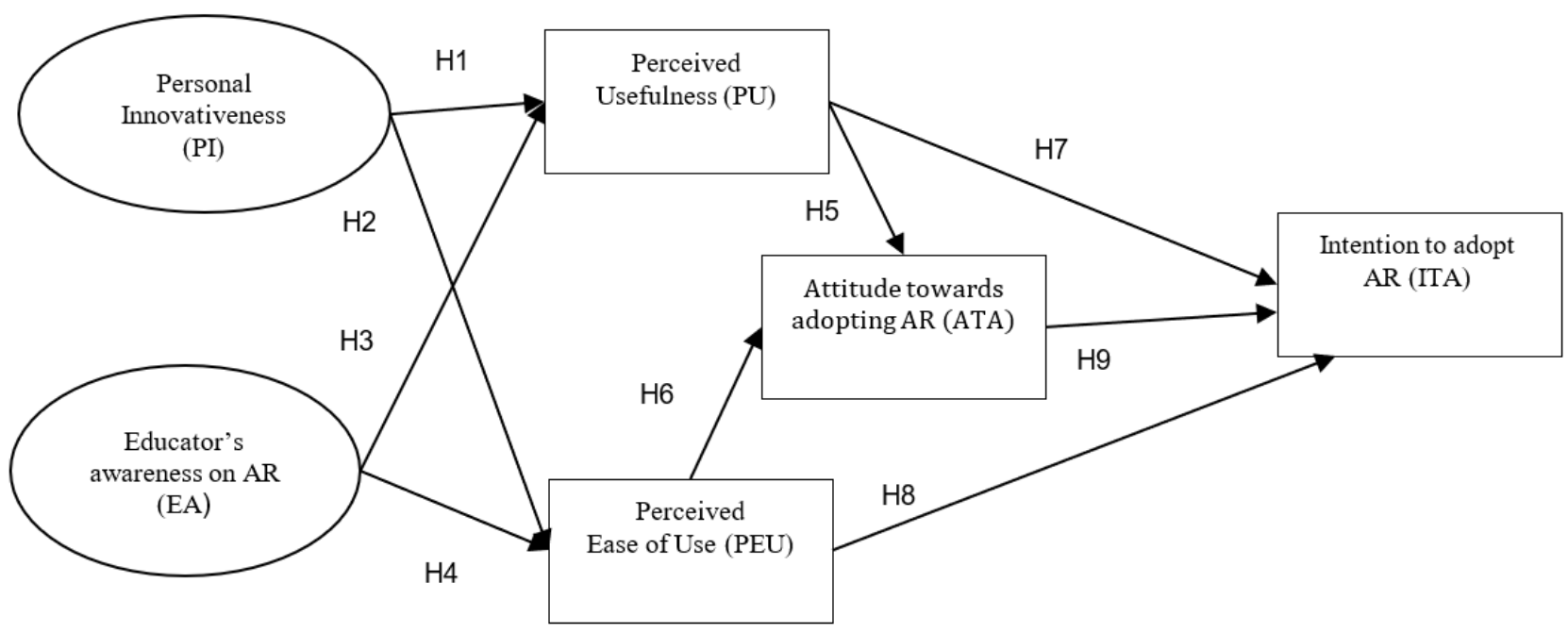

\section{METHODOLOGY}

This quantitative study employed a questionnaire survey that was distributed to educators from five private universities in Malaysia upon approval from the universities. After filtering 350 questionnaires that were given to respondents, 223 valid questionnaires were computed into the Statistical Packages for Social Sciences (SPSS) software version 23.0 to generate a descriptive analysis of the respondents' profile. The data were also analysed using the Partial Least Squares - Structural Equation Modelling (PLS-SEM) software version 3.0 to generate the inferential analysis.

The questionnaire was comprised of two sections. Section A pertained to demographic questions such as gender, ethnicity, age, marital status, and highest educational level, while Section B was made of items to be scaled using the 5 -points Likert scale ranging from 1 representing "strongly disagree" to 5 representing "strongly agree". All measurement items are presented in Table $\mathbf{1}$. 
Table 1. Measurement items

\begin{tabular}{|c|c|}
\hline Constructs & Items Descriptions \\
\hline Awareness of AR & $\begin{array}{l}\text { AW1 I am aware that AR can be used as teaching aids. } \\
\text { AW2 I know that AR enables us to see the image using AR applications. } \\
\text { AW3 I know that AR can be applied in various fields. }\end{array}$ \\
\hline $\begin{array}{l}\text { Educator's } \\
\text { innovative }\end{array}$ & $\begin{array}{l}\text { I enjoy teaching my students via the digital learning platform. (i.e: Kahoot, Blendspace). } \\
\text { I am up-to-date with the new digital technology in education. } \\
\text { I feel confident with digital technology in education. } \\
\text { I often search for better teaching aids. }\end{array}$ \\
\hline $\begin{array}{l}\text { Perceived } \\
\text { usefulness }\end{array}$ & $\begin{array}{l}\text { PU1 I believe that AR will enhance my teaching preparation effectively. } \\
\text { PU2 } \\
\text { BU3 } \\
\text { Using able to use AR as my teaching aid will be useful. } \\
\text { PU4 } \\
\text { I can effectively manage my teaching with AR designing. } \\
\text { PU5 }\end{array}$ \\
\hline $\begin{array}{l}\text { Perceived ease of } \\
\text { use }\end{array}$ & $\begin{array}{l}\text { PEU1 I feel comfortable to explore AR in my teaching as a teaching tool. } \\
\text { PEU2 I feel convenient in using AR as my teaching aid. } \\
\text { PEU3 I have fun using AR as my teaching aid. } \\
\text { PEU4 I feel that it is easy to use AR in my teaching. } \\
\text { PEU5 It will be easy for me to be skillful in IT when using AR. } \\
\text { PEU6 My interaction with AR will be clearer. }\end{array}$ \\
\hline $\begin{array}{l}\text { Attitude to adopt } \\
\text { AR }\end{array}$ & $\begin{array}{l}\text { AT1 I like the idea of using AR as an enhancement for teaching aid. } \\
\text { AT2 I think using AR in my teaching plan is a good idea. } \\
\text { AT3 I think AR enables my students to enjoy the reality of the images. } \\
\text { AT4 I feel good with AR designing in my teaching plan. } \\
\text { AT5 I am able to accept AR as my teaching aid. } \\
\text { AT6 I feel good about adopting AR in my teaching. }\end{array}$ \\
\hline $\begin{array}{l}\text { Intention to adopt } \\
\text { AR }\end{array}$ & $\begin{array}{ll}\text { IN1 } & \text { I intend to use AR as my teaching aid. } \\
\text { IN2 } & \text { I would like to use AR in my daily teaching. } \\
\text { IN3 } & \text { I am interested to include AR in my teaching plan. } \\
\text { IN4 } & \text { I will apply AR in my teaching materials. } \\
\text { IN5 } & \text { I will use AR soon. } \\
\text { IN6 } & \text { I would recommend my colleague to use AR as their teaching aid. }\end{array}$ \\
\hline
\end{tabular}

\section{RESULTS}

\section{Descriptive Analysis}

As presented in figures below, $66.37 \%$ of the respondents were female with ages ranging from 31 to 35 years old. Among the respondents, 147 participants (65.92\%) were married. In addition, 39.91\% of the respondents were Malay, another 39.91\% were Chinese, and 16.59\% were Indians. Most participants (63.68\%) possessed a Master's degree, while $22.87 \%$ possessed a Doctorate. Over $65 \%$ of the respondents were aware of the AR technology before this study. 


\section{Ethnic}

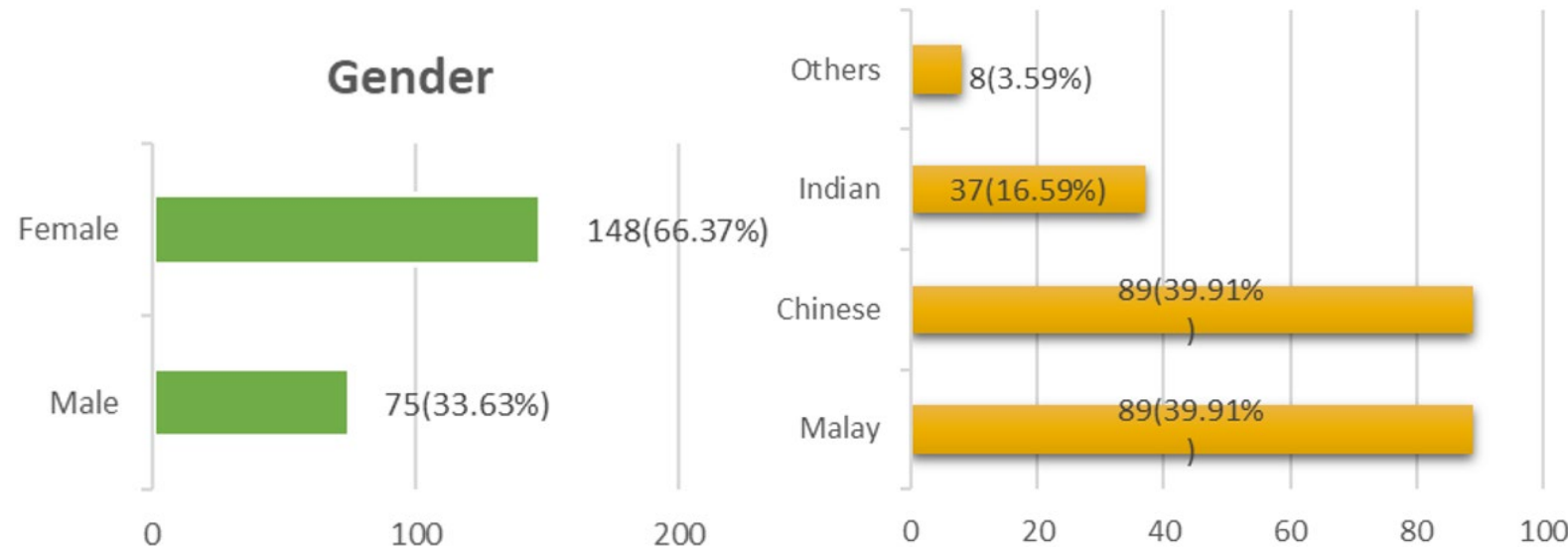

\section{Age}

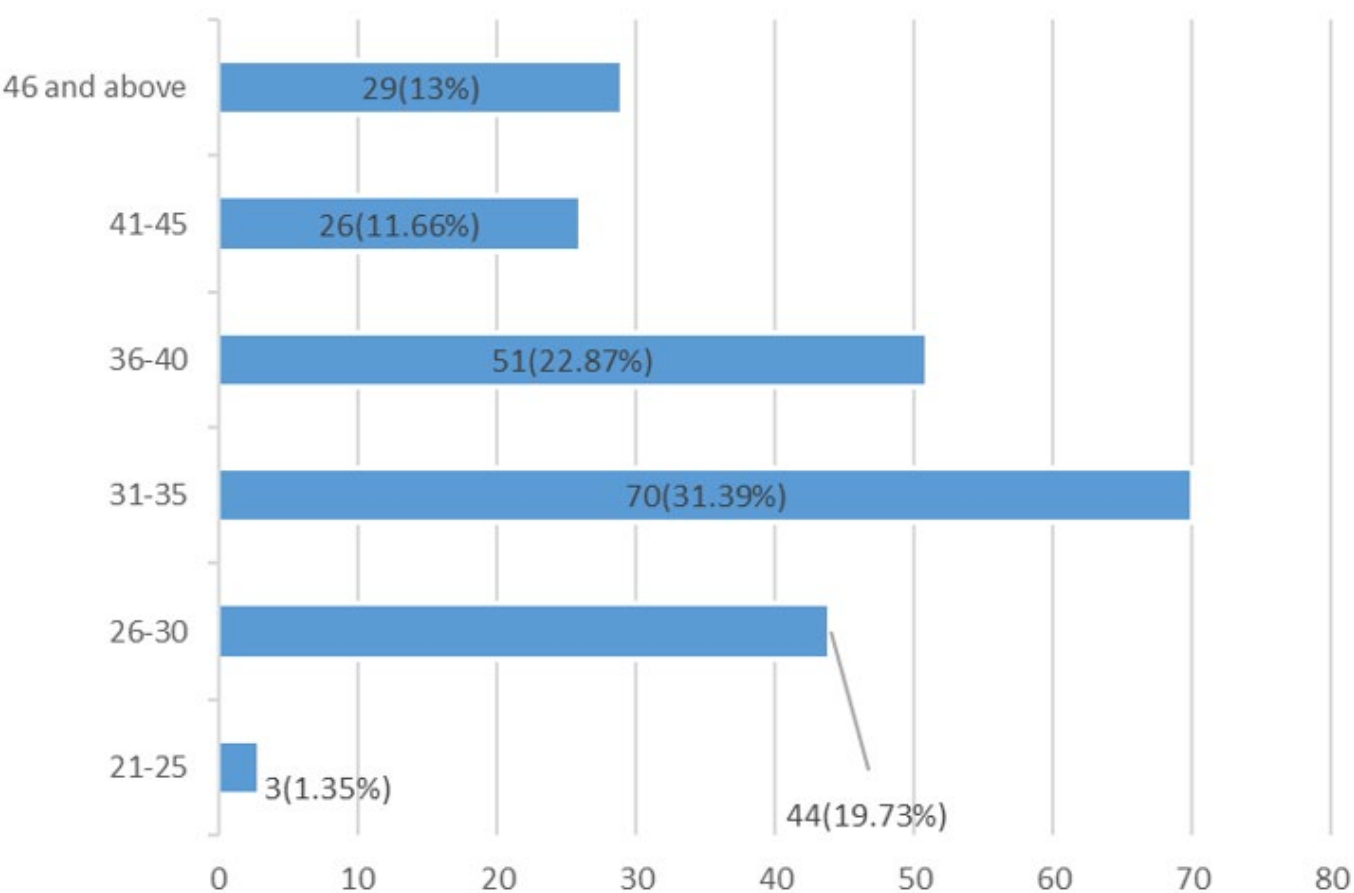

\section{Marital Status}

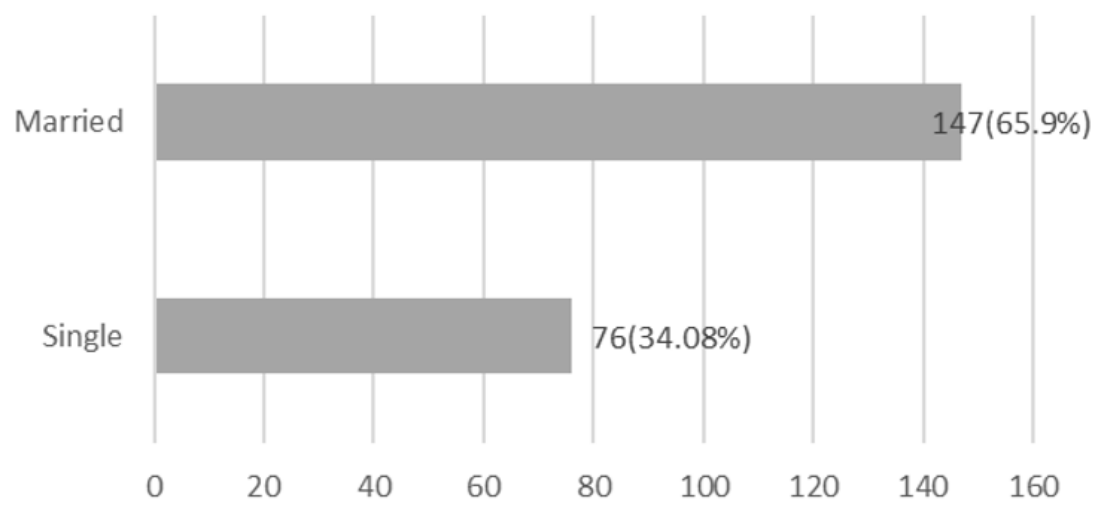




\section{Highest Education Level}

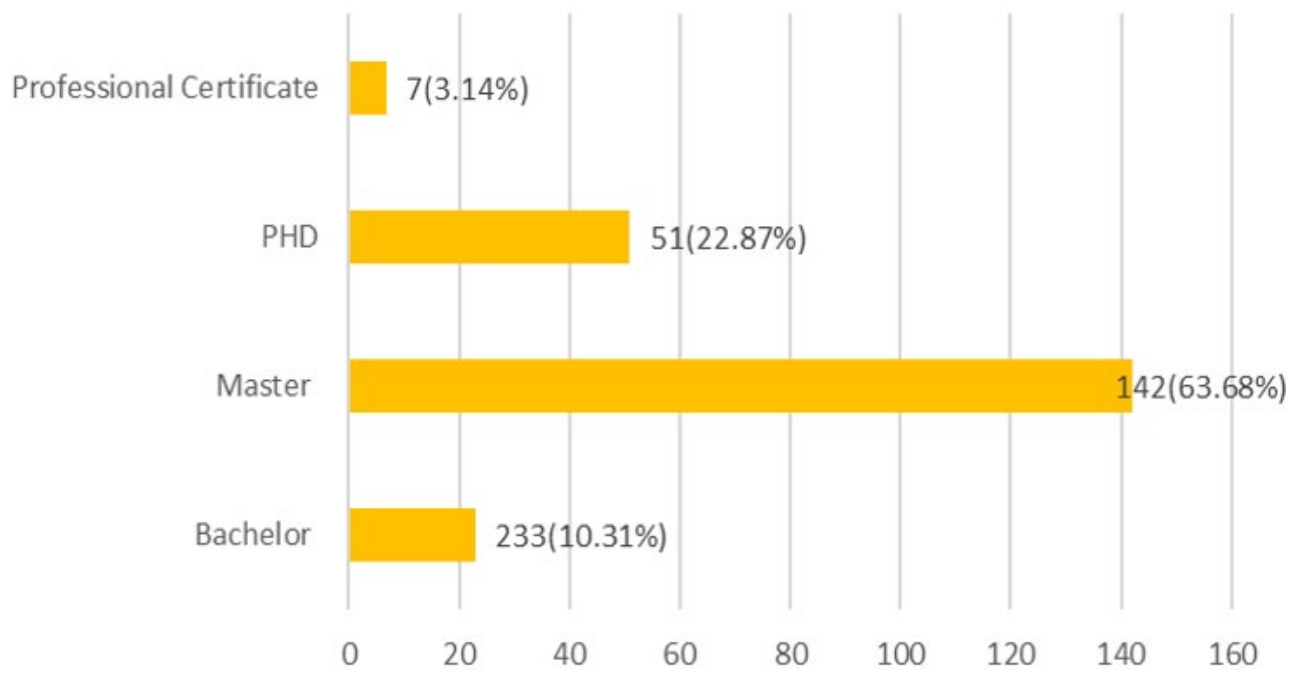

Have you heard about AR?

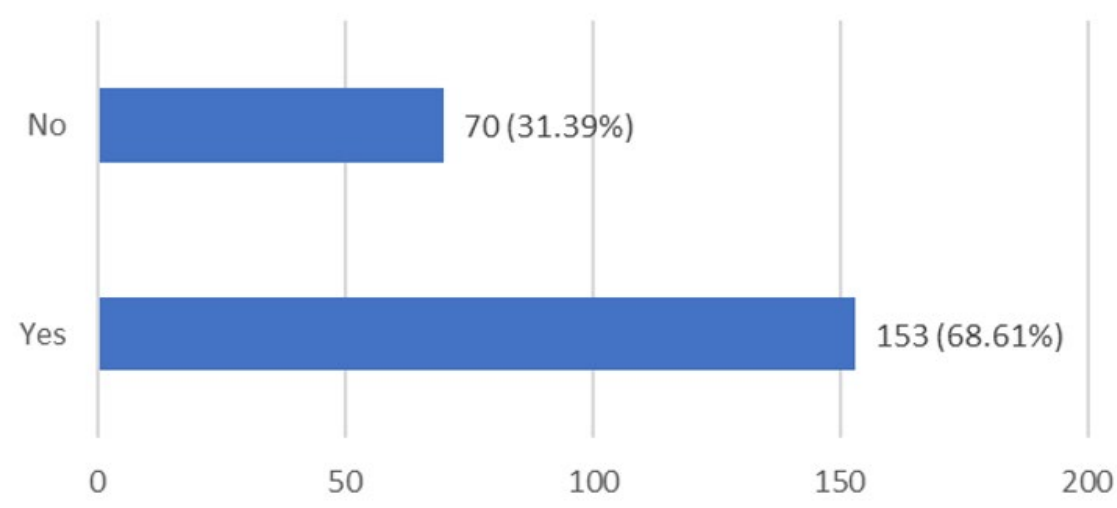

\section{Measurement Model}

\section{Convergent validity}

The latent constructs' convergent validity was analysed using standardised factor loading $(>0.6)$, extraction of the average variance (AVE $>0.5$ ), and composition reliability (CR $>0.7$ ) (Hair et al., 2010). Table 2 shows that the value of factor loading for all items (attitude to adopt AR, awareness on AR, educator's innovation, intention to adopt AR, PEU, and PU) were over 0.7 of the recommended value (Chin, Gopal, \& Salisbury, 1997). The reliability values for each construct ranged from 0.801 to 0.931 were fulfilled by the composite reliability threshold value of 0.7 (Hair et al., 2010), while the Average Variance Extracted (AVE) for each of the constructs ranged from 0.638 to 0.744 were above the threshold of 0.5 (Hair et al., 2010). 
Table 2. Factor loading and reliability

\begin{tabular}{|c|c|c|c|c|c|}
\hline Variable & Items & Loading & Composite Reliability & Average Variance Extracted & Cronbach Alpha \\
\hline \multirow[t]{6}{*}{ Attitude to adopt AR } & AT1 & 0.860 & 0.910 & 0.692 & 0.931 \\
\hline & AT2 & 0.869 & & & \\
\hline & AT3 & 0.750 & & & \\
\hline & AT4 & 0.851 & & & \\
\hline & AT5 & 0.822 & & & \\
\hline & AT6 & 0.831 & & & \\
\hline \multirow[t]{3}{*}{ Awareness of AR } & AW1 & 0.831 & 0.807 & 0.721 & 0.886 \\
\hline & AW2 & 0.821 & & & \\
\hline & AW3 & 0.893 & & & \\
\hline \multirow[t]{3}{*}{ Educator's innovation } & EI1 & 0.818 & 0.801 & 0.715 & 0.883 \\
\hline & $\mathrm{E} 12$ & 0.879 & & & \\
\hline & $\mathrm{EI} 3$ & 0.838 & & & \\
\hline \multirow[t]{6}{*}{ Intention to adopt AR } & IN1 & 0.879 & 0.931 & 0.744 & 0.946 \\
\hline & IN2 & 0.808 & & & \\
\hline & IN3 & 0.906 & & & \\
\hline & IN4 & 0.909 & & & \\
\hline & IN5 & 0.871 & & & \\
\hline & IN6 & 0.797 & & & \\
\hline \multirow[t]{6}{*}{ Perceived ease of use } & PEU1 & 0.879 & 0.896 & 0.660 & 0.921 \\
\hline & PEU2 & 0.808 & & & \\
\hline & PEU3 & 0.906 & & & \\
\hline & PEU4 & 0.909 & & & \\
\hline & PEU5 & 0.871 & & & \\
\hline & PEU6 & 0.797 & & & \\
\hline \multirow[t]{5}{*}{ Perceived usefulness } & PU1 & 0.866 & 0.857 & 0.638 & 0.897 \\
\hline & PU2 & 0.888 & & & \\
\hline & PU3 & 0.720 & & & \\
\hline & PU4 & 0.734 & & & \\
\hline & PU5 & 0.771 & & & \\
\hline
\end{tabular}

Table 3. Discriminant validity

\begin{tabular}{lcccccc}
\hline Variable & ATA & AW & ITA & PEU & EI & PU \\
\hline Attitude to adopt AR (ATA) & 0.832 & & & & & \\
Awareness on AR (AW) & 0.574 & 0.849 & & & & \\
Intention to adopt AR (ITA) & 0.765 & 0.467 & 0.863 & & & \\
Perceived ease of use (PEU) & 0.677 & 0.482 & 0.726 & 0.812 & & \\
Educator's innovation (EI) & 0.500 & 0.386 & 0.504 & 0.569 & 0.846 & \\
Perceived usefulness (PU) & 0.669 & 0.528 & 0.602 & 0.654 & 0.438 & 0.799 \\
\hline
\end{tabular}

\section{Discriminant validity}

Discriminant validity is an analysis to determine the correlation between the variables to ensure low correlations between variables by using heterotrait-monotrait (HTMT). As shown in Table 3, the value of discriminant validity for each construct was less than the square root of the average variance extracted and passed the HTMT threshold.

After the composite reliability and the discriminant validity were confirmed, bootstrapping was tested using 5000 resamplings to access the significance of the path coefficients. The results are presented in Table 4 . Meanwhile, the $t$-value can be compared with a critical value for significance levels of 5 per cent or the probability of error is 1.96 (two-tailed test). All the results were supported except for the PU towards ITA. 
Table 4. Summary of the structural model

\begin{tabular}{lcccc}
\hline Variable & Hypothesis & Path coefficient & t-value & Results \\
\hline Educator's innovation -> Perceived usefulness & $\mathrm{H} 1$ & 0.275 & $4.440^{* * *}$ & Supported \\
Educator's innovation -> Perceived ease of use & $\mathrm{H} 2$ & 0.450 & $6.300^{* * *}$ & Supported \\
Awareness of AR -> Perceived usefulness & $\mathrm{H} 3$ & 0.422 & $6.718^{* * *}$ & Supported \\
Awareness on AR -> Perceived ease of use & $\mathrm{H} 4$ & 0.309 & $5.086^{* * *}$ & Supported \\
Perceived usefulness -> Attitude to adopt AR & $\mathrm{H} 5$ & 0.395 & $5.558^{* * *}$ & Supported \\
Perceived ease of use -> Attitude to adopt AR & $\mathrm{H} 6$ & 0.418 & $6.128^{* * *}$ & Supported \\
Perceived usefulness -> Intention to adopt AR & $\mathrm{H} 7$ & 0.024 & 0.330 & Not Supported \\
Perceived ease of use -> Intention to adopt AR & $\mathrm{H} 8$ & 0.370 & $5.438^{* * *}$ & Supported \\
Attitude to adopt AR -> Intention to adopt AR & $\mathrm{H} 9$ & 0.501 & $6.282^{* * *}$ & Supported \\
\hline
\end{tabular}

Note: all $\mathrm{p}$-values are two-tailed, * significant at $0.05, * * *$ significant at 0.001

\section{DISCUSSION}

The results demonstrate that there is a significant relationship among educators' innovation towards intention to adopt AR moderated by PU and PEU at 0.05 levels, which is consistent with Cheng et al.'s (2012) study, which demonstrates that managerial support and job support can influence the acceptance of elearning system through PU. The findings are also consistent with Hassanzadeh et al. (2012) and Motaghian et al. (2013), suggesting that educators' innovation awareness on AR influenced both PEU and PU.

Furthermore, Hypothesis 5 and Hypothesis 6, showing that PU and PEU significantly influence educators' attitude in adopting AR at 0.05 levels, which is consistent with Motaghian et al.'s (2013) study on web-based learning systems in two e-learning pioneer universities in Iran. Nonetheless, this research observes that PEU (path coefficient $=0.418$ ) has stronger impacts on the educator's attitude to adopt AR compared to PU (path coefficient $=0.395$ ). The results suggest that AR can improve students' learning engagement.

Based on Table 4, Hypothesis 7 is rejected, implying that PU impacted ITA at a 5\% significance level. The result supports Hassanzadeh et al.'s (2012) research on e-learning in Tehran Universities. Also, the attitude to adopt AR has a $5 \%$ significance level on the impact on the intention to adopt AR.

The findings are consistent with previous studies, agreeing that AR transforms dull instructions into exciting learning environment (Ibáñez et al., 2014; Lu \& Liu, 2015) and making AR-based games leads learning more entertaining (Bressler \& Bodzin, 2013; Mohd Yusof et al., 2014; Muñoz Cristóbal et al., 2015), increasing students' engagement and performance (Chang et al., 2014; Liu \& Tsai, 2013). The results support the findings of previous studies - AR can enhance the teaching and learning process (Chung \& Tan, 2004; Wu, Chen, \& Lin, 2007; Yuen \& Ma, 2002; Teo \& Noyes, 2011). It is also observed that educators are ready to implement $A R$ as a teaching enhancement tool.

\section{CONCLUSION}

The move to online learning caused by the unexpected outbreak of the COVID-19 pandemic gives a rise to $A R$ prominence. Following this observation, this paper has examined the applications of $A R$ as an enhancement teaching tool through the TAM. Previous studies have observed that AR reshape monotonous instructions to an interactive learning environment (Ibáñezet al., 2014; Kim et al., 2018; Lu \& Liu, 2015; Savela et al., 2020). To further assess this notion, this research analysed 223 valid questionnaire surveys to investigate the application of AR in learning using the SPSS and Partial Least Squares - Structural Equation Modelling (PLS-SEM). Based on Table 4, the structural model demonstrates that AR plays a role in teaching, supporting the observations of previous studies (Chung \& Tan, 2004; Teo Noyes, 2011; Wu et al., 2007; Yuen \& Ma, 2002).

Nevertheless, the results are limited to only private universities in Penisular Malaysia and do not consider the role of the universities' top management as one of the variables. Future researches may consider recruiting students as respondents. This insightful study may be of interest to the government, learning 
institutions, educators, and others on the implementation of AR in Malaysia's educational sector. The implementation of this study may accelerate Malaysia's move towards Industrial Resolution 4.0 and the exploration of IoT, in addition to strengthening the education sector and increasing the effectiveness in nurturing future leaders.

Author contributions: All authors were involved in concept, design, collection of data, interpretation, writing, and critically revising the article. All authors approve final version of the article.

Funding: The study received financial support from Universiti Tunku Abdul Rahman, Malaysia under the Universiti Tunku Abdul Rahman Research Fund (UTARRF).

Declaration of interest: Authors declare no competing interest.

Data availability: Data generated or analysed during this study are available from the authors on request.

\section{REFERENCES}

Abrar, M. F., Islam, M. R., Hossain, M. S., Islam, M. M., \& Kabir, M. A. (2019). Augmented reality in education: A study on preschool children, parents, and teachers in Bangladesh. In International Conference on Human-Computer Interaction (pp. 217-229). Springer. https://doi.org/10/1007/978-3-030-215651_14

Acosta, J. L. B., Navarro, S. M. B., Gesa, R. F., \& Kinshuk, K. (2019). Framework for designing motivational augmented reality applications in vocational education and training. Australasian Journal of Educational Technology, 35(3), 102-117. https://doi.org/10.14742/ajet.4182

Akçayır, M., \& Akçayır, G. (2017). Advantages and challenges associated with augmented reality for education: A systematic review of the literature. Educational Research Review, 20, 1-11. https://doi.org/10.1016/j.edurev.2016.11.002

Alalwan, A. A., Baabdullah, A. M., Rana, N. P., Tamilmani, K., \& Dwivedi, Y. K. (2018). Examining adoption of mobile internet in Saudi Arabia: Extending TAM with perceived enjoyment, innovativeness and trust. Technology in Society, 55, 100-110. https://doi.org/10.1016/j.techsoc.2018.06.007

Al-Daihani, S. M. (2016). Students' adoption of Twitter as an information source: An exploratory study using the Technology Acceptance Model. Malaysian Journal of Library \& Information Science, 21(3), 57-69. https://doi.org/10.22452/mjlis.vol21no3.4

Azuma, R. T. (1997). A Survey of Augmented Reality. Presence, 6(4), 355-385. https://doi.org/10.1162/pres.1997.6.4.355

Bressler, D. M., \& Bodzin, A. M. (2013). A mixed methods assessment of students' flow experiences during a mobile augmented reality science game. Journal of computer assisted learning, 29(6), 505-517. https://doi.org/10.1111/jcal.12008

Bujak, K. R., Radu, I., Catrambone, R., Maclntyre, B., Zheng, R., \& Golubski, G. (2013). A psychological perspective on augmented reality in the mathematics classroom. Computers and Education, 68, 536544. https://doi.org/10.1016/j.compedu.2013.02.017

Bursali, H., \& Yilmaz, R. M. (2019). Effect of augmented reality applications on secondary school students' reading comprehension and learning permanency. Computers in Human Behavior, 95, 126-135. https://doi.org/10.1016/j.chb.2019.01.035

Chang, Y. S., Hu, K. J., Chiang, C. W., \& Lugmayr, A. (2020). Applying Mobile Augmented Reality (AR) to Teach Interior Design Students in Layout Plans: Evaluation of Learning Effectiveness Based on the ARCS Model of Learning Motivation Theory. Sensors, 20(1), 105. https://doi.org/10.3390/s20010105

Cheng, K.-H. (2018). Surveying Students' Conceptions of Learning Science by Augmented Reality and their Scientific Epistemic Beliefs. Eurasia Journal of Mathematics, Science and Technology Education, 14(4), 1147-1159. https://doi.org/10.29333/ejmste/81811 
Cheng, B., Wang, M., Moormann, J., Olaniran, B. A., \& Chen, N. S. (2012). The effects of organizational learning environment factors on e-learning acceptance. Computers \& Education, 58(3), 885-899. https://doi.org/10.1016/j.compedu.2011.10.014

Chang, K.-E., Chang, C.-T., Hou, H.-T., Sung, Y.-T., Chao, H.-L., \& Lee, C.-M. (2014). Development and behavioral pattern analysis of a mobile guide system with augmented reality for painting appreciation instruction in an art museum. Computers \& Education, 71, 185-197. https://doi.org/10.1016/j.compedu.2013.09.022

Cheng, K. H., \& Tsai, C. C. (2013). Affordances of Augmented Reality in Science Learning: Suggestions for Future Research. Journal of Science Education and Technology, 22(4), 449-462. https://doi.org/10.1007/s10956-012-9405-9

Chin, W. W., Gopal, A, \& Salisbury W. D. (1997). Advancing the theory of adaptive structuration: the development of a scale to measure faithfulness of appropriation. Information Systems Research, 8(4), 342-367. https://doi.org/10.1287/isre.8.4.342

Chung, J., \& Tan, F. B. (2004). Antecedents of perceived playfulness: an exploratory study on user acceptance of general information-searching websites. Information and Management, 41(7), 869-881. https://doi.org/10.1016/j.im.2003.08.016

Davis, F. D. (1989). Perceived usefulness, perceived ease of use, and user acceptance of information technology. MIS Quarterly, 13(3), 319-340. https://doi.org/10.2307/249008

Ebenezer, J., Kaya, O. N., \& Kassab, D. (2018). High School Students' Reasons for Their Science Dispositions: Community-Based Innovative Technology-Embedded Environmental Research Projects. Research in Science Education, 1-25. https://doi.org/10.1007/s11165-018-9735-6

Fathema, N., Shannon, D., \& Ross, M. (2015). Expanding the Technology Acceptance Model (TAM) to examine faculty use of Learning Management Systems (LMSs) in higher education institutions. Journal of Online Learning \& Teaching, 11(2), 210-232. https://jolt.merlot.org/Vol11no2/Fathema_0615.pdf

Fuchsova, M., \& Korenova, L. (2019). Visualisation in Basic Science and Engineering Education of Future Primary School Teachers in Human Biology Education Using Augmented Reality. European Journal of Contemporary Education, 8(1), 92-102. https://doi.org/10.13187/ejced.2019.1.92

Gan, C. L., \& Balakrishnan, V. (2018). Mobile Technology in the Classroom: What Drives Student-Lecturer Interactions? International Journal of Human-Computer Interaction, 34(7), 666-679. https://doi.org/10.1080/10447318.2017.1380970

Garzón, J., \& Acevedo, J. (2019). Meta-analysis of the impact of Augmented Reality on students' learning gains. Educational Research Review, 27(March), 244-260. https://doi.org/10.1016/j.edurev.2019.04.001

Garzón, J., Pavón, J., \& Baldiris, S. (2019). Systematic review and meta-analysis of augmented reality in educational settings. Virtual Reality, 23(4), 447-459. https://doi.org/10.1007/s10055-019-00379-9

Hair, J. F, Black, W. C., Babin, B. J., \& Anderson, R. E. (2010). Multivariate data analysis. Prentice- Hall.

Hassanzadeh, A., Kanaani, F., \& Elahi, S. (2012). A model for measuring e-learning systems success in universities. Expert Systems with Applications, 39(12), 10959-10966. https://doi.org/10.1016/j.eswa.2012.03.028

Hiranyachattada, T., \& Kusirirat, K. (2020). Using mobile augmented reality to enhancing students' conceptual understanding of physically-based rendering in 3D animation. European Journal of Science and Mathematics Education, 8(1), 1-5. https://files.eric.ed.gov/fulltext/EJ1242139.pdf

Hockly, N. (2019). Augmented reality. ELT Journal, 73(3), 328-334. https://doi.org/10.1093/elt/ccz020 
Huang, C. Y., Wang, H. Y., Yang, C. L., \& Shiau, S. J. (2020). A derivation of factors influencing the diffusion and adoption of an open source learning platform. Sustainability, 12(18), 7532. https://doi.org/10.3390/su12187532

Huang, Y., Li, H., \& Fong, R. (2016). Using Augmented Reality in early art education: a case study in Hong Kong kindergarten. Early Child Development and Care, 186(6), 879-894.

Ibáñez, M. B., Di Serio, Á., Villarán, D., \& Kloos, C. D. (2014). Experimenting with electromagnetism using augmented reality: Impact on flow student experience and educational effectiveness. Computers \& Education, 71, 1-13. https://doi.org/10.1080/03004430.2015.1067888

Kaewunruen, S. (2019). Enhancing railway engineering student engagement using interactive technology embedded with infotainment. Education Sciences, 9(2), 136. https://doi.org/10.3390/educsci9020136

Karakus, M., Ersozlu, A., \& Clark, A. C. (2019). Augmented Reality Research in Education: A Bibliometric Study. Eurasia Journal of Mathematics, Science and Technology Education, 15(10), em1755. https://doi.org/10.29333/ejmste/103904

Kim, S. J., Jeong, Y., Park, S., Ryu, K., \& Oh, G. (2018). A survey of drone use for entertainment and AVR (augmented and virtual reality). In Augmented Reality and Virtual Reality (pp. 339-352). Springer. https://doi.org/10.1007/978-3-319-64027-3_23

Kiryakova, G., Angelova, N., \& Yordanova, L. (2018). The potential of augmented reality to transform education into Smart education. TEM Journal, 7(3), 556-565. https://doi.org/10.33578/pjr.v3i4.7433

Kugelmann, D., Stratmann, L., Nühlen, N., Bork, F., Hoffmann, S., Samarbarksh, G., Pferschy, A., Von Der Heide, A.M., Eimannsberger, A., Fallavollita, P., \& Navab, N. (2018). An augmented reality magic mirror as additive teaching device for gross anatomy. Annals of Anatomy-Anatomischer Anzeiger, 215, 71-77. https://doi.org/10.1016/j.aanat.2017.09.011

Lee, K. (2012). Augmented Reality in Education and Training. TechTrends, 56(2), 13-21. https://doi.org/10.1007/s11528-012-0559-3

Lee, J., Kim, J., \& Choi, J. Y. (2019). The adoption of virtual reality devices: The technology acceptance model integrating enjoyment, social interaction, and strength of the social ties. Telematics and Informatics, 39, 37-48. https://doi.org/10.1016/j.tele.2018.12.006

Lin, H. C. K., Chen, M. C., \& Chang, C. K. (2015). Assessing the effectiveness of learning solid geometry by using an augmented reality-assisted learning system. Interactive Learning Environments, 23(6), 799810. https://doi.org/10.1080/10494820.2013.817435

Liu, P. H. E., \& Tsai, M. K. (2013). Using augmented-reality-based mobile learning material in EFL English composition: An exploratory case study. British Journal of Educational Technology, 44(1), E1-E4. https://doi.org/10.1111/j.1467-8535.2012.01302.x

López Belmonte, J., Moreno-Guerrero, A. J., López Núñez, J. A., \& Pozo Sánchez, S. (2019). Analysis of the Productive, Structural, and Dynamic Development of Augmented Reality in Higher Education Research on the Web of Science. Applied Sciences, 9(24), 5306. https://doi.org/10.3390/app9245306

Lu, S. J., \& Liu, Y. C. (2015). Integrating augmented reality technology to enhance children's learning in marine education. Environmental Education Research, 21(4), 525-541. https://doi.org/10.1080/13504622.2014.911247

Ma, M., Fallavollita, P., Seelbach, I., Von Der Heide, A. M., Euler, E., Waschke, J., \& Navab, N. (2016). Personalized augmented reality for anatomy education. Clinical Anatomy, 29(4), 446-453. https://doi.org/10.1002/ca.22675 
Masmuzidin, M. Z., \& Aziz, N. A. A. (2018). The current trends of augmented reality in early childhood education. The International Journal of Multimedia \& Its Applications (IJMA), 10(6), 47. https://doi.org/10.5121/ijma.2018.10605

Mohd Yusof, A., Daniel, E. G. S., Low, W. Y., \& Ab. Aziz, K. (2014). Teachers' perception of mobile edutainment for special needs learners: The Malaysian case. International Journal of Inclusive Education, 18(12), 1237-1246. https://doi.org/10.1080/13603116.2014.885595

Moro, C., Štromberga, Z., Raikos, A., \& Stirling, A. (2017). The effectiveness of virtual and augmented reality in health sciences and medical anatomy. Anatomical Sciences Education, 10(6), 549-559. https://doi.org/10.1002/ase.1696

Motaghian, H., Hassanzadeh, A., \& Moghadam, D. K. (2013). Factors affecting university instructors' adoption of web-based learning systems: Case study of Iran. Computers \& Education, 61, 158-167. https://doi.org/10.1016/j.compedu.2012.09.016

Muñoz Cristóbal, J. A., Prieto, L. P., Asensio Pérez, J. I., Martínez Monés, A., Jorrín Abellán, I. M., \& Dimitriadis Damoulis, I. (2015). Coming down to Earth: Helping teachers use 3D virtual worlds in across-spaces learning situations. Journal of Educational Technology \& Society, 18(1), 13-26. https://www.jstor.org/stable/jeductechsoci.18.1.13

Ozdemir, M., Sahin, C., Arcagok, S., \& Demir, M. K. (2018). The Effect of Augmented Reality Applications in the Learning Process: A Meta-Analysis Study. Eurasian Journal of Educational Research, 74, 165-186. https://dergipark.org.tr/en/pub/ejer/issue/42528/512469

Pikkarainen, T., Pikkarainen, K., Karjaluoto, H., \& Pahnila, S. (2004). Consumer acceptance of online banking: an extension of the technology acceptance model. Internet Research. https://doi.org/10.1108/10662240410542652

Porter, M. E., \& Heppelmann, J. E. (2017). A Manager's Guide to Augmented Reality. Harvard Business Review, 95(6), 45-57.

Richardson, D. (2016). Exploring the potential of a location based augmented reality game for language learning. International Journal of Game-Based Learning (IJGBL), 6(3), 34-49. https://doi.org/10.4018/IJGBL.2016070103

Savela, N., Oksanen, A., Kaakinen, M., Noreikis, M., \& Xiao, Y. (2020). Does Augmented Reality Affect Sociability, Entertainment, and Learning? A Field Experiment. Applied Sciences, 10(4), 1392. https://doi.org/10.3390/app10041392

Scherer, R., Siddiq, F., \& Tondeur, J. (2019). The technology acceptance model (TAM): A meta-analytic structural equation modeling approach to explaining teachers' adoption of digital technology in education. Computers \& Education, 128, 13-35. https://doi.org/10.1016/j.compedu.2018.09.009

Shapley, K., Sheehan, D., Maloney, C., \& Caranikas-Walker, F. (2011). Effects of technology immersion on middle school students' learning opportunities and achievement. The Journal of Educational Research, 104(5), 299-315. https://doi.org/10.1080/00220671003767615

Siyam, N. (2019). Factors impacting special education teachers' acceptance and actual use of technology. Education and Information Technologies, 24(3), 2035-2057. https://doi.org/10.1007/s10639-01809859-y

Squires, D. (2017). Augmented Reality Application Classroom Development: New Technology and New Media, Education and Intelligent Classrooms. i-Manager's Journal of Educational Technology, 14(1), 1. https://files.eric.ed.gov/fulltext/EJ1269051.pdf

Sutherland, I. E. (1968). A head-mounted three dimensional display. In Proceedings of the December 9-11, 1968, fall joint computer conference, part I (pp. 757-764). https://doi.org/10.1145/1476589.1476686 
Teeroovengadum, V., Heeraman, N., \& Jugurnath, B. (2017). Examining the antecedents of ICT adoption in education using an extended technology acceptance model (TAM). International Journal of Education and Development Using ICT, 13(3), 4-23. https://www.learntechlib.org/p/182155/

Tekedere, H., \& Göker, H. (2016). Examining the Effectiveness of Augmented Reality Applications in Education: A Meta-Analysis. International Journal of Environmental \& Science Education, 11(16), 94699481. https://eric.ed.gov/?id=EJ1118774

Teo, T., \& Noyes, J. (2011). An assessment of the influence of perceived enjoyment and attitude on the intention to use technology among pre-service teachers: A structural equation modeling approach. Computers \& education, 57(2), 1645-1653. https://doi.org/10.1016/j.compedu.2011.03.002

Weng, N. G., Bee, O. Y., Yew, L. H., \& Hsia, T. E. (2016). An augmented reality system for biology science education in Malaysia. International Journal of Innovative Computing, 6(2), 8-13. http://se.fc.utm.my/index.php/ijic/article/viewFile/128/58

Wojciechowski, R., Walczak, K., White, M., \& Cellary, W. (2004). Building virtual and augmented reality museum exhibitions. In Proceedings of the ninth international conference on 3D Web technology (pp. 135-144). https://doi.org/10.1145/985040.985060

Wu, H. K., Lee, S. W. Y., Chang, H. Y., \& Liang, J. C. (2013). Current status, opportunities and challenges of augmented reality in education. Computers and Education, 62, 41-49. https://doi.org/10.1016/j.compedu.2012.10.024

Wu, J. H., Chen, Y. C., \& Lin, L. M. (2007). Empirical evaluation of the revised end user computing acceptance model. Computers in Human Behavior, 23(1), 162-174. https://doi.org/10.1016/j.chb.2004.04.003

Yip, J., Wong, S. H., Yick, K. L., Chan, K., \& Wong, K. H. (2019). Improving quality of teaching and learning in classes by using augmented reality video. Computers \& Education, 128, 88-101. https://doi.org/10.1016/j.compedu.2018.09.014

Yuen, A., \& Ma, W. (2002). Gender differences in teacher computer acceptance. Journal of Technology and Teacher Education, 10(3), 365-382. https://www.learntechlib.org/primary/p/15142/

Zaineldeen, S., Hongbo, L., \& Hassan, B. M. A. (2020). Technology Acceptance Model' Concepts, Contribution, Limitation, and Adoption in Education. Universal Journal of Educational Research, 8(11), 5061-5071. https://doi.org/10.13189/ujer.2020.081106

Correspondence: Chooi Yi Wei, Universiti Tunku Abdul Rahman, Perak, Malaysia. E-mail: weicy@utar.edu.my 